\begin{tabular}{|l|l|l|l|l|l|} 
J. Tek. Ling & Vol.11 & No.2 & Hal. 227 - 237 & Jakarta, Mei 2010 & ISSN 1441-318X \\
\hline
\end{tabular}

\title{
PERHITUNGAN FAKTOR EMISI \\ DI SISTEM JARINGAN KETENAGALISTRIKAN JAWA-MADURA-BALI
}

\author{
Irhan Febijanto \\ Peneliti di Pusat Teknologi Pengembangan Sumberdaya Energi, \\ Badan Pengkajian dan Penerapan Teknologi
}

\begin{abstract}
The methodology of calculation for emission factor for grid connection is determined by IPCCC Intergovernmental Panel Climate Change). The methodology is revised periodically, and become comprehensive calculation. Mainly in developed countries, the emission factor is provided by government related institution yearly. Therefore the developers who need that value can get easily, and they can save a time and money in the developing Clean Development Mechanism Project. In Indonesia, until now there is no government institution or other related institutions that have an obligation to provide and calculate that number. PTPSE-BPPT has initiated to calculate the emission factor of grid system of Jawa-MaduraBali using data between 2002 and 2006. The Approved Consolidated Methodology 0002 and Approved Methodology Simple I-D were used in the calculation. Based on the calculation result, it was proved that the emission factor of JAMALI grid increased $18.2 \%$, resulted to coal consumption increased. The value of this emission factor has been adopted by Directorate General Electricity and energy Utilization and recognized by Indonesian Designated National Authority, as a National Number of emission factor in JAMALI in 2008.
\end{abstract}

\section{Keywords : faktor emisi, emisi karbon, sistem JAMALI, pembangkit listrik, Clean Development Mechanism,}

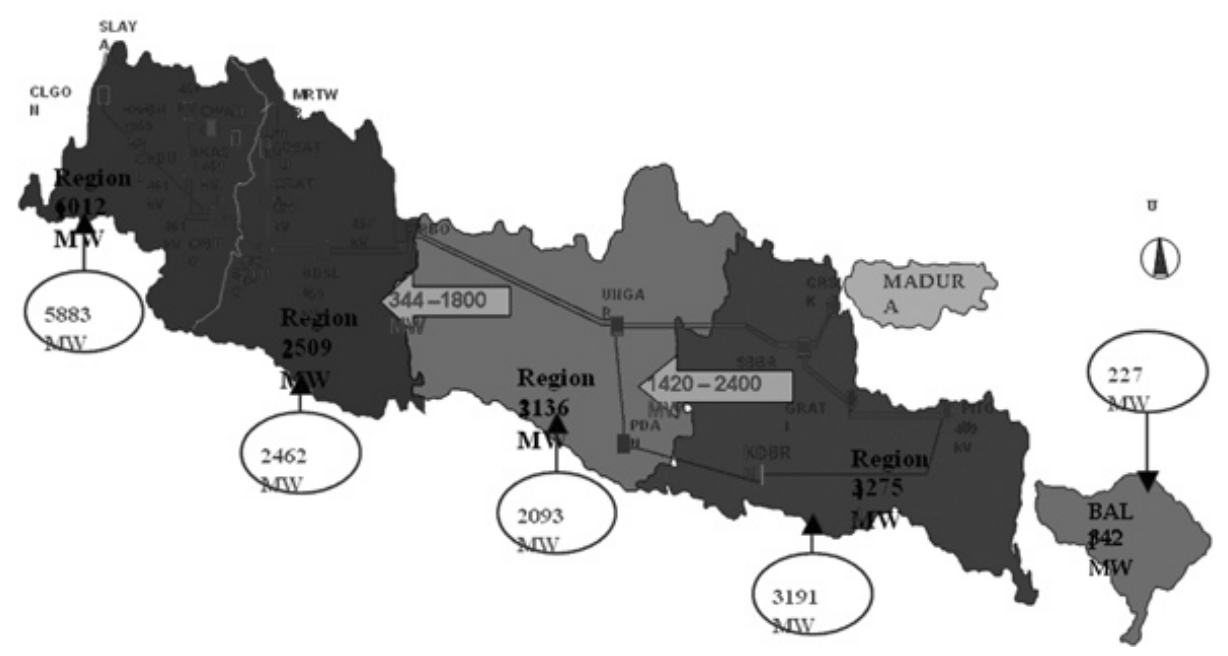

Gambar 1. Sistem Ketenagalistrikan Jawa-Madura-Bali 


\section{PENDAHULUAN}

\subsection{Latar Belakang}

Untuk membantu memecahkan permasalahan pemanasan global secara lokal, maka dirasakan perlu melakukan perhitungan Emission Factor, EF untuk sistem ketenagalistrikan Jawa-Madura Bali (sistem JAMALI, gambar 1) Perhitungan ini akan membantu pemerintah Indonesia sendiri, dalam membuat perencanaan dalam mengurangi emisi GRK (Gas Rumah Kaca) terutama di sektor energi, khususnya emisi GRK yang dihasilkan oleh kegiatan pembangkit listrik yang terkoneksi di jaringan JAMALI. Angka EF juga membantu Departement Lingkungan Hidup untuk mempromosikan Indonesia sebagai negara yang berpotensi untuk memberikan kontribusi pengurangan emisi gas GRK secara global. Di samping itu angka EF juga dipakai oleh para investor CDM untuk menentukan jumlah pengurangan emisi karbon dari proyek yang mereka rencanakan.

Perhitungan EF, pernah dilakukan oleh Chevron Texaco yang membentuk tim nasional pada tahun $2006^{(1)}$, namun sayang kelanjutan dari tim ini tidak ada sehingga perhitungan EF tidak mengalami pembaharuan. Pembaruan nilai EF tiap tahun ini dipandang perlu mengingat pembangunan Pusat Pembangkit Listrik di Indonesia ini sangat cepat karena adanya Program Percepatan Pembangunan PLTU Batubara dengan total $1000 \mathrm{MW}^{(2)}$.

Sampai saat ini di Indonesia belum ada institusi pemerintah maupun swasta yang berwenang atau pun berkewajiban memberikan perhitungan EF. Hal ini berbeda dengan beberapa negara maju seperti Jepang dan negara - negara Eropa, dimana pihak pemerintahnya memberikan angka EF yang menjadi acuan dari kebijakan pemerintah untuk mengurangi gas GRK dan angka tersebut dapat dipakai dengan bebas tanpa biaya oleh para pengembang/investor pembangkit yang berminat mengajukan proyeknya ke dalam mekanisme CDM.

\subsection{Tujuan}

Tujuan dari perhitungan ini adalah memberikan pembaharuan angka Emisi Faktor untuk sistem kelistrikan JAMALI untuk kurun waktu 2004-2007. Angka ini dibutuhkan untuk memprediksi jumlah emisi GRK yang dihasilkan untuk setiap pembangkit yang terkoneksi dengan jaringan kelistrikan JAMALI.

Data perhitungan yang dipakai adalah energi listrik yang dibangkitkan oleh seluruh pembangkit listrik yang tersambung dengan jaringan ketenagalistrikan di sistem JAMALI dan jumlah konsumsi bahan bakar dalam kurun waktu 2002-2006. Dari kurun waktu tersebut untuk penentuan EF, hanya data rata-rata dari kurun waktu 2004-2007 yang dipakai untuk perhitungan.

\section{METODOLOGI}

Metodologi perhitungan dilakukan sesuai dengan metodologi terbaru yang telah ditetapkan oleh Executive Board, yaitu Tool to calculate the emission factor for an electricity system" (3). Metoda ini merupakan tatacara yang digunakan IPCC untuk menetapkan parameter-parameter yang didefinisikan sesuai dengan ACM002 (Approved Consolidation Methodology 0002) version ke 7, "Consolidated methodology for grid-connected electricity generation from renewable sources". (4) dan AMS I.D (Approved Methodology) untuk tipe : renewable energy dengan kategori ID (version 11) : "grid connected renewable electricty generation ${ }^{(5)}$.

\subsection{Emisi Karbon dari Pembangkit Listrik}

Perhitungan emisi karbon yang dihasilkan dari pembakaran bahan bakar fosil kegiatan operasional unit pembangkit listrik dihitung nilai - nilai parameter yang dikeluarkan berdasarkan IPCCC (Intergovernmental Panel on Climate 
Change) dan PERTAMINA (Perusahaan Minyak Nasional) seperti ditunjukkan di tabel 4. Jumlah volume bahan bakar dan energi listrik yang dibangkitkan diambil dari buku Statistik PLN(6), (7), (8), (9), (10) dan anak perusahaannya(11), (12), (13), (14), (15), (16)terbitan tahun 2002-2006. Khusus untuk batubara diambil dari sumber yang berbeda(17), (18).

Data dari PLN dan anak perusahaan selalu diterbitkan dengan keterlambatan sekitar 2 tahun. Walaupun perhitungan ini dilaksanakan tahun 2008, namun data statistik terbaru yang ada adalah tahun 2006. Hal ini terjadi pada pihak Chevron, yang menghitung EF pada tahun 2006, dengan data terbaru tahun 2004.

\subsection{Faktor Emisi Karbon}

Dalam perhitungan Faktor Emisi system JAMALI, yang menjadi target perhitungan adalah jumlah karbondioksida $\left(\mathrm{CO}_{2}\right)$ yang dihasilkan oleh pusat pembangkit yang telah ada/beroperasi dihitung sesuai dengan metodologi yang telah ditetapkan oleh UNFCCC.

Berdasarkan metodologi "Consolidated methodology for grid-connected electricity generation from renewable sources". (4) dan AMS I.D (Approved Methodology) untuk tipe : renewable energy dengan kategori ID (version 11) : "grid connected renewable electricty generation ${ }^{\left({ }^{8}\right)}$ jumlah bahan bakar yang dikonsumsi pusat pembangkit listrik yang dikoneksikan ke sistem JAMALI selama kurun waktu 3 tahun terakhir berturutturut dikonversikan ke dalam jumlah emisi karbon melalui langkah-langkah perhitungan tertentu.

Pada studi ini, hasil perhitungan koefisien faktor emisi sistem JAMALI, merupakan hasil perbaikan dari hasil perhitungan Chevron-Texaco Co.(1) yang dilaksanakan pada proyek CDM untuk PLTP (Pembangkit Listrik Tenaga Panas Bumi) Darajad unit 3. Namun karena angka tersebut memakai data lama, diperlukan pembaharuan untuk mendukung perhitungan proyek-proyek CDM saat ini, dan untuk mendukung prediksi potensi pengurangan emisi $\mathrm{CO}_{2}$ yang dihasilkan pusat pembangkit listrik saat ini dan masa yang akan datang.

Langkah-langkah perhitungan Faktor Emisi , EF, adalah sebagai berikut ${ }^{(3)}$,

Langkah 1. Penentuan Faktor Emisi Operating Margin (EF

Metoda Simple Operating Margin (OM) dipilih ${ }^{(6)}$ untuk perhitungan faktor emisi Operating Margin karena alasan sebagai berikut :

1. Dispatch Data Analysis Emission Factor tidak dapat dipenuhi karena data-data yang dibutuhkan tidak dapat dipublikasikan.

2. Pembangkit yang termasuk kategori "Low-Cost and Must-Run/LCMR" jumlah nya kurang $50 \%$ dari total seluruh pembangkit yang terkoneksi ke grid JAMALI dalam kurun waktu 5 tahun (2001-2005).

Emisi Faktor Simple Operating Margin dihitung dengan menggunakan persamaan seperti di bawah ini.

$$
g e, y\left(t O_{2} / M W h\right)=\frac{\sum_{i, j} F_{i, j y} \cdot \operatorname{COEF}_{i, j}}{\sum_{i} G E N_{i, y}}
$$

Perhitungan Faktor Emisi Build Margin menunjukkan besarnya emisi $\mathrm{CO}_{2}$ ketika pembangunan pembangkit listrik berbahan bakar fosil tidak dibangun, atau pembangunannya mengalami pemunduran waktu.

Perhitungan $\mathrm{EF}_{\mathrm{BM}, \mathrm{y}^{\prime}}$, dipilih sekumpulan unit pembangkit yang baru dibangun dimana dari kumpulan grup unit pembangkit tersebut dipilih unit pembangkit yang mempunyai jumlah produksi daya listrik yang terbesar di tiap tahun dengan pemilihan sebagai berikut : 
1. Lima unit pembangkit yang terakhir selesai dibangun, atau

2. Penambahan kapasitas pembangkit ke dalam sistem kelistrikan dengan jumlah $20 \%$ dari total kapasitas sistem kelistrikan (dalam MWh), dan unit pembangkit-pembangkit tersebut baru selesai dibangun.

Dari kumpulan/grup pembangkit tersebut, dipilih yang menghasilkan energi listrik yang lebih besar untuk menghitung Emisi faktor Build Margin dihitung dengan persamaan.

dimana,

\begin{tabular}{|c|l|l|}
\hline $\mathrm{F}_{\mathrm{i}, \mathrm{j}, \mathrm{y}}$ & $:$ & $\begin{array}{l}\text { Jumlah bahan bakar, i (massa } \\
\text { atau volume) yang dikonsumsi } \\
\text { pembangkit yang terkait, j di tahun } \\
\text { y (2002-2006) }\end{array}$ \\
\hline $\mathrm{j}$ & $:$ & $\begin{array}{l}\text { Pembangkit yang menyalurkan } \\
\text { listrik ke grid, tetapi tidak termasuk } \\
\text { pembangkit yang termasuk } \\
\text { low-operating cost and must } \\
\text { run power plants pembangkit } \\
\text { yang berbahan bakar energi } \\
\text { terbarukan }{ }^{(7)} .\end{array}$ \\
\hline $\mathrm{COEF}$ & $:$ & $\begin{array}{l}\text { Koefisien emisi CO }{ }_{2} \text { emission } \\
\text { untuk bahan bakar i (tCO } / \text { mass } \\
\text { it,jau volume untuk tiap unit bahan } \\
\text { bakar), dipakai untuk menghitung } \\
\text { kandungan karbon tiap bahan } \\
\text { bakar di tiap pembangkit } \\
\text { pembangkit, j. }\end{array}$ \\
\hline GEN & $:$ & $\begin{array}{l}\text { Besarnya daya .listrik (MWh) } \\
\text { yang dikoneksikan ke grid dari } \\
\text { pembangkit j pada tahun y. }\end{array}$ \\
\hline
\end{tabular}

Langkah 2, Perhitungan emisi factor build margin $\left(\mathrm{EF}_{\mathrm{BM}, \mathrm{y}}\right)$

$$
\mathrm{EF}_{\mathrm{BM}, \mathrm{y}}\left(\mathrm{tCO}_{2} / \mathrm{MWh}\right)=\frac{\sum_{\mathrm{i}, \mathrm{m}} \mathrm{F}_{\mathrm{i}, \mathrm{m}, \mathrm{y}} \cdot \mathrm{COEF}_{\mathrm{i}, \mathrm{m}}}{\sum_{\mathrm{m}} \mathrm{GEN}_{\mathrm{m}, \mathrm{y}}}
$$

dimana,

$F_{i, m, y^{\prime}}, \operatorname{COEF}_{i, m}$ and GEN $_{m, y}$ dianalogikan sebagai variable yang sama seperti pada metodologi perhitungan OM untuk kelompok unit pembangkit, $\mathrm{m}$.
Langkah 3. Perhitungan baseline emission factor (combined margin emission factor $\left(E_{y}\right)$

$E F_{y}=w_{O M} E F_{O M, y}+w_{B M} E F_{B M}$

Dimana, perbandingan untuk $w_{O M}$ and $w_{B M}$, ditentukan masing-masing $50 \%\left(w_{O M}=w_{B M}\right.$ $=0.5$ ).

Langkah 4, Perhitungan baseline emission (BE)

Baseline emission dihitung sebagai berikut

$$
\mathrm{BE}_{\mathrm{y}}\left(\mathrm{tCO}_{2} \mathrm{e} / \mathrm{year}\right)=\mathrm{EG}_{\mathrm{y}}{ }^{*} \mathrm{EF}_{\mathrm{y}}
$$

Langkah 5, Perhitungan pengurangan emisi $\left(E R_{Y}\right)$

$\mathrm{ER}_{\mathrm{y}}=\mathrm{BE}_{\mathrm{y}}-\mathrm{PE} \mathrm{E}_{\mathrm{y}}-\mathrm{Ly}_{\mathrm{y}}$

Pada proyek ini tidak ada kebocoran, $\mathrm{L}_{\mathrm{y}}=0$, dan karena merupakan pembangkit energi terbarukan maka kebocoran dan Emisi Proyek tidak ada, $\mathrm{PE}_{\mathrm{y}}=0$.

$$
\begin{aligned}
& E F_{\text {grid, }, C M, y}=E F_{\text {grid, }, \text { MM , }} \times w_{O M}+E F_{\text {grid, } B M, y} \times \\
& w_{B M} \cdots \cdots(6)
\end{aligned}
$$

\begin{tabular}{|c|c|c|}
\hline $\mathrm{EF}_{\text {grid, } \mathrm{CM}, \mathrm{y}}$ & $=$ & $\begin{array}{l}\text { Combined margin } \mathrm{CO}_{2} \\
\text { emissions factor dalam tahun } \\
y\left(\mathrm{tCO}_{2} / \mathrm{MWh}\right)\end{array}$ \\
\hline $\mathrm{EF}_{\text {grid, } \mathrm{BM}, \mathrm{y}}$ & $=$ & $\begin{array}{l}\text { Build margin } \mathrm{CO}_{2} \text { emission } \\
\text { factor dalam tahun y }\left(\mathrm{tCO}_{2} /\right. \\
\mathrm{MWh})\end{array}$ \\
\hline $\mathrm{EF}_{\text {grid, } \mathrm{OM}, \mathrm{y}}$ & $=$ & $\begin{array}{l}\text { Operating margin } \mathrm{CO}_{2} \\
\text { emission factor dalam tahun y } \\
\left.\text { ( } \mathrm{tCO}_{2} / \mathrm{MWh}\right)\end{array}$ \\
\hline $\mathrm{w}_{\mathrm{OM}}$ & $=$ & $\begin{array}{l}\text { Besaran dari operation } \\
\text { margin emissions factor }(\%) \\
(=50 \%)\end{array}$ \\
\hline$W_{B M}$ & $=$ & $\begin{array}{l}\text { Besaran dari build margin } \\
\text { emissions factor }(\%)\end{array}$ \\
\hline
\end{tabular}

dimana:

Dimana Build Margin dan Operating Margin $\mathrm{CO}_{2}$ Emission Factor ditentukan oleh persamaan (7) dan (8), yang tertulis di bawah ini. 


$$
E F_{\text {grid,OMaverage, } y}=\frac{\sum_{i} F_{i, y} \bullet N C V_{i, y} \bullet E F_{C O 2, i, y}}{E G_{y}}
$$

dimana:

\begin{tabular}{|l|l|l|}
\hline $\mathrm{EF}_{\text {grid,omaverage,y }}$ & $=\begin{array}{l}\text { Average operating margin CO } \\
\text { emission factor dalam tahun } \mathrm{y}^{2} \\
\text { (tCO /MWh) }\end{array}$ \\
\hline $\mathrm{FC}_{\mathrm{i}, \mathrm{y}}$ & $=\begin{array}{l}\text { Jumlah bahan bakar fosil tipe } \\
\text { i yang dikonsumsi oleh sebuah } \\
\text { system proyek pembangkit listrik } \\
\text { dalam tahun y }\end{array}$ \\
\hline $\mathrm{NCV}_{\mathrm{i}, \mathrm{y}}$ & $=\begin{array}{l}\text { Net calorific value bahan bakar } \\
\text { fosil tipe i dalam tahun y (GJ / } \\
\text { mass or volume unit) }\end{array}$ \\
\hline $\mathrm{EF}_{\mathrm{coz}, \mathrm{i}, \mathrm{y}}$ & $=\begin{array}{l}\text { Faktor emisi CO dari bahan } \\
\text { bakar fosil tipe i dalam tahun y } \\
\text { (tCO /GJ) }\end{array}$ \\
\hline $\mathrm{EG}_{\mathrm{y}}$ & $=\begin{array}{l}\text { Net lístrik yang dibandkitkan dan } \\
\text { disalurkan ke system grid yang } \\
\text { disuplai oleh seluruh pembangkit } \\
\text { listrik, termasuk low-cost / must- } \\
\text { run power plants / units, dalam } \\
\text { tahun y (MWh) }\end{array}$ \\
\hline $\mathrm{i}$ & $=\begin{array}{l}\text { Seluruh tipe bahan bakar } \\
\text { fosil yang dibakar di seluruh } \\
\text { pembangkit listrik di sistem yang } \\
\text { tersambung dengan pembangkit } \\
\text { listrik di proyek ini dalam tahun y }\end{array}$ \\
\hline $\mathrm{y}$ & $=\begin{array}{l}\text { Tahun yang menunjukkan } \\
\text { waktu data terbaru saat itu yang } \\
\text { memungkinkan untuk diserahkan } \\
\text { ke validator untuk memenuhi } \\
\text { prosedur CDM. }\end{array}$ \\
\hline
\end{tabular}

NCV (Net Caloric Value) yang dipakai dalam studi ini ditunjukkan di tabel 3.

$$
E F_{g r i d, B M, y}=\frac{\sum_{m} E G_{m, y} \bullet E F_{B L, m, y}}{\sum_{m} E G_{m, y}}
$$

dimana :

\begin{tabular}{|l|l|l|}
\hline $\mathrm{EF}_{\text {grid, } \mathrm{BM}, \mathrm{y}}$ & $=\begin{array}{l}\text { Build margin } \mathrm{CO}_{2} \text { emission } \\
\text { factor dalam tahun } \mathrm{y}\left(\mathrm{tCO}_{2} /\right. \\
\mathrm{MWh})\end{array}$ \\
\hline $\mathrm{EG}_{\mathrm{m}, \mathrm{y}}$ & $=\begin{array}{l}\text { Jumlah net listrik yang dibang- } \\
\text { kit kan dan disuplaikan ke grid } \\
\text { dari unit pembangkit listrik } m \\
\text { dalam tahun } \mathrm{y}(\mathrm{MWh})\end{array}$ \\
\hline $\mathrm{EF}_{\mathrm{EL}, \mathrm{m}, \mathrm{y}}$ & $=\begin{array}{l}\text { Faktor emisi } \mathrm{CO}_{2} \text { untuk unit } \\
\text { pembangkit listrik } m \text { dalam } \\
\text { tahun } y \text { (tCO } / \mathrm{MWh})\end{array}$ \\
\hline $\mathrm{m}$ & $=\begin{array}{l}\text { Unit-unit pembangkit listrik } \\
\text { yang termasuk dalam perhi- } \\
\text { tungan build margin. }\end{array}$ \\
\hline $\mathrm{y}$ & $=\begin{array}{l}\text { Tahun-tahun terbaru yang be- } \\
\text { rurutan untuk data pembangkit } \\
\text { listrik. }\end{array}$ \\
\hline
\end{tabular}

Dari hasil persamaan (7) dan (8) didapat dua faktor emisi, yang kemudian kedua nilai faktor tersebut digabungkan sesuai dengan persamaan (3), sehingga didapat Combined margin $\mathrm{CO}_{2}$ emissions factor.

\section{HASIL DAN PEMBAHASAN}

\subsection{Kondisi Operasi dan Konsumsi Bahan Bakar Pembangkit di sistem JAMALI}

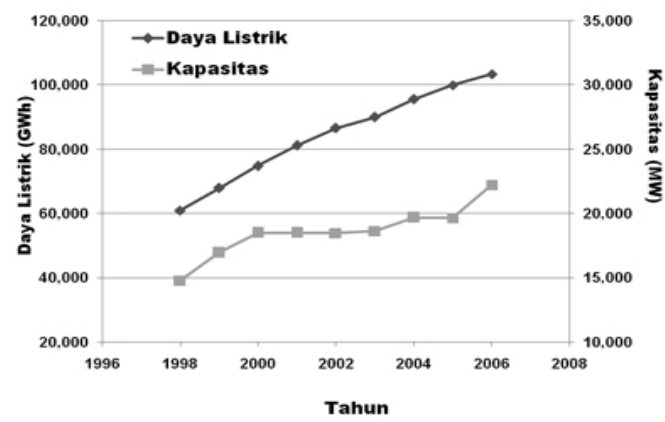

Gambar 2 Pertumbuhan Kapasitas Pembangkit \& Daya Listrik Yang Dibangkitkan Dalam Kurun Waktu 5 tahun

Gambar 2, menunjukkan pertambahan kapasitas pembangkit dan daya listrik yang dibangkitkan di sistem JAMALI dalam kurun waktu 9 tahun (1998-2006). Sumbu tegak sebelah kiri menunjukkan besarnya daya listrik yang dibangkitkan, dan sumbu tegak sebelah kanan menunjukkan kapasitas pembangkit di sistem JAMALI. Pertumbuhan daya listrik dalam kurun waktu di atas adalah sesuai dengan peningkatan kebutuhan pasokan listrik di sistem, dimana dari tahun ke tahun mengalami kenaikan sebesar rata-rata antara $5-10 \%$. Tanda panah pada gambar 2 menunjukkan kurun waktu 20022006, data yang dipakai dalam perhitungan Faktor Emisi tahun 2006, EF $_{2006}$.

Kenaikan kebutuhan pasokan listrik tidak diikuti dengan peningkatan kapasitas listrik, dimana dalam kurun waktu 20002004, pertumbuhan kapasitas pembangkit tidak mengalami peningkatan. Kondisi ini 


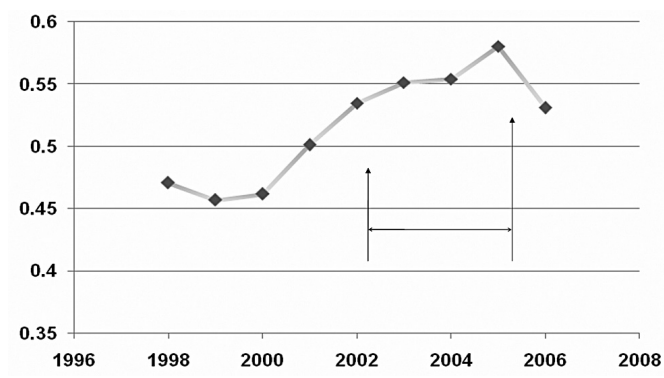

Gambar 3 Kapasitas Faktor Rata-rata di Sistem JAMALI

menyebabkan peningkatan kapasitas faktor rata - rata $\left(\mathrm{CF}_{\text {average }}\right)$ untuk pembangkit yang terkoneksi di sistem JAMALI meningkat seperti ditunjukkan pada gambar 3. Pada tahun 2006 dengan penambahan kapasitas pembangkit PLTU batubara Tanjung Jati B (1320 MW) dan PLTGU gas Cilegon (740 $\mathrm{MW}), \mathrm{CF}$ average turun drastis sebesar $5 \%$.

Peningkatan konsumsi bahan bakar jelas akan meningkatkan emisi karbon. Besarnya jumlah emisi karbon, selain bergantung kepada jumlah konsumsi bahan bakar, juga bergantung kepada efisiensi panas pembagkit itu sendiri, dimana efisiensi panas pembangkit akan berubah-ubah bergantung kepada load factor pembangkit. Semakin tinggi load faktor (mendekati 100\%) maka nilai efisiensi panas pembangkit akan mendekati nilai disain efisiensi panas, atau dengan kata lain, semakin tinggi load faktor pembangkit maka pembangkit tersebut akan semakin efisien.

Dari gambar 4 dapat diketahui rasio emisi karbon terhadap konsumsi bahan bakar untuk membangkitkan $1 \mathrm{kWh}$ di sistem JAMALI. Emisi karbon ini merupakan hasil pembagian dari nilai rata rata emisi karbon yang dihasilkan oleh seluruh pembangkit di sistem JAMALI dalam satu tahun dibagi dengan jumlah daya listrik yang dibangkitkan oleh pembangkit tersebut dalam kurun waktu 1 tahun.

Besaran emisi karbon ini selain bergantung kepada kandungan karbon dan

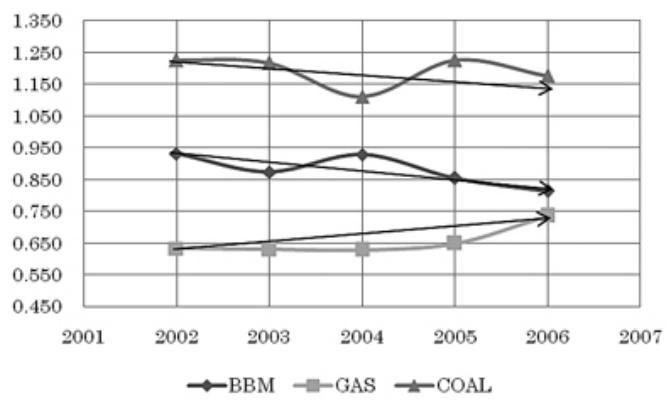

Gambar 4 Perubahan Rasio Emisi Karbon Tiap Bahan Bakar

nilai kalor dari masing masing pembangkit, juga bergantung kepada efisiensi panas dari pembangkit. Parameter nilai kalor dan kandungan karbon adalah tetap, sedangkan efisiensi panas pembangkit akan selalu berubah bergantung kepada sistem pengoperasian pembangkit, seperti telah dijelaskan sebelumnya.

Dari gambar 4 ditunjukkan bahwa rasio emisi karbon untuk batubara adalah terbesar dibandingkan dengan gas dan BBM (Bahan Bakar Minyak), sehingga untuk membangkitkan $1 \mathrm{kWh}$ bahan bakar batubara akan menghasilkan emisi karbon lebih banyak dibandingkan dengan gas dan BBM. BBM terdiri dari bahan bakar MFO (Marine Fuel Oil), HSD (High Speed Diesel) dan IDO (Industrial Diesel Oil). Rasio batubara dan BBM cenderung mengalami penurunan dalam kurun waktu 2001-2006, sedangkan untuk gas mengalami kenaikan. Peningkatan kebutuhan listrik yang meningkat tidak diikuti dengan penambahan kapasitas pembangkit diduga menyebabkan kenaikan load factor di tiap tiap pembangkit, Hal ini menyebabkan kenaikan efisiensi pembangkit, atau dengan kata lain karena pengoperasian load faktor pembangkit meningkat maka pada saat itu pengoperasian efisiensi panas pembangkit mendekati nilai disain efisiensi panas pembangkit. Dalam kondisi ini, rasio emisi karbon akan cenderung menurun. Rasio emisi karbon ini sangat bergantung kepada efisiensi panas pembangkit. Kecenderungan penurunan rasio emisi karbon batubara dan 
BBM ditunjukkan dengan jelas di gambar 4. Kenaikan rasio emisi karbon pada gas disebabkan karena penurunan konsumsi gas dari tahun ke tahun. Pada tahun 2004 terjadi penurunan rasio batubara dan kenaikan pada BBM.

Peningkatan kebutuhan listrik yang diikuti dengan peningkatan daya listrik selama kurun waktu 5 (2002-2006), juga diikuti dengan peningkatan konsumsi bahan bakar. Komposisi bahan bakar ditunjukkan di gambar 5. Rasio jumlah konsumsi BBM cenderung mengalami kenaikan, konsumsi batubara juga cenderung mengalami kenaikan dan mencapai nilai tertinggi pada tahun 2004, sedangkan gas mengalami penurunan dari tahun ke tahun. Kondisi perubahan jumlah konsumsi BBM \& batubara ini mempengaruhi perubahan rasio emisi karbon untuk kedua bahan bakar ini pada tahun 2004 seperti yang ditunjukkan gambar 4.

Dari komposisi bahan bakar pembangkit di sistem JAMALI sebagaimana ditunjukkan pada di gambar 5, rasio penggunaan batubara, mendominasi lebih dari $65 \%$ yang diikuti oleh BBM. Sedangkan konsumsi gas cenderung turun dari tahun ke tahun.

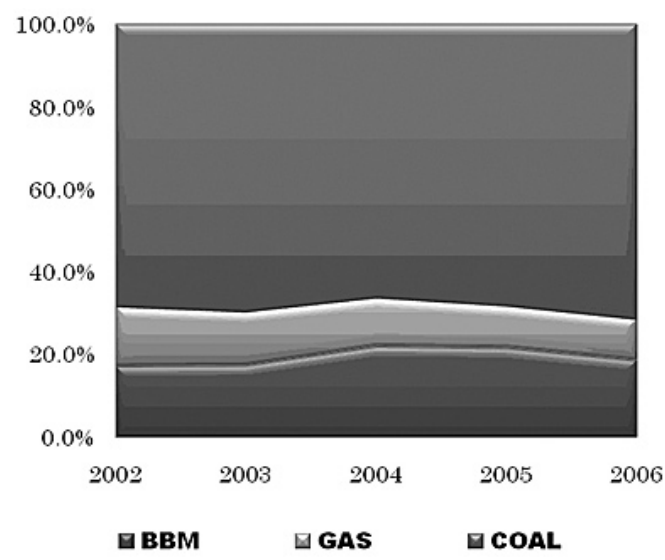

Gambar 5. Komposisi Bahan Bakar Penghasil Emisi Karbon
Peningkatan emisi karbon dari batubara ini diprediksi akan meningkat tajam dalam kurun waktu 2-3 tahun mendatang sejalan dengan beroperasinya PLTU batu bara yang telah diprogramkan pembangunannya oleh pemerintah melakukan beberapa percepatan pembangunan PLTU $10.000 \mathrm{MW}^{(5)}$.Secara kuantitatif jumlah emisi karbon dalam kurun waktu 5 tahun (2002-2006) meningkat dari $67.833 \mathrm{kt}-\mathrm{CO}_{2}$ menjadi $86.824 \mathrm{kt}-\mathrm{CO}_{2}$. Peningkatan ini seperti dijelaskan di atas dikarenakan adanya peningkatan jumlah konsumsi bahan bakar dan peningkatan rasio konsumsi batubara.

Dari kondisi ini diketahui dengan jelas komposisi pembangkit di sistem JAMALI yang didominasi oleh PLTU batubara, merupakan salah tahu kondisi yang menyebabkan emisi karbon akan terus meningkat dari tahun ke tahun.

\subsection{Perhitungan Operating Margin}

Dari data pemakaian bahan bakar di jaringan JAMALI selama kurun waktu 5 tahun (2002-2006) dan, produksi listrik, yang ditunjukkan di tabel 1 dan tabel 2 , dengan memakai persamaan 7 dilakukan perhitungan $\mathrm{EF}_{\mathrm{OM}(2003-2005)}$.

Tabel 1. Konsumsi Bahan Bakar pada Sistem JAMALI tahun 2002-2006(6)(7)(8)

\begin{tabular}{|l|l|l|l|l|l|l|}
\hline \multirow{2}{*}{$\begin{array}{c}\text { Fuel } \\
\text { type }\end{array}$} & \multirow{2}{*}{ unit } & \multicolumn{5}{|c|}{ year } \\
\cline { 3 - 7 } & & 2002 & \multicolumn{1}{|c|}{2003} & 2004 & \multicolumn{1}{|c|}{2005} & \multicolumn{1}{|c|}{2006} \\
\hline HSD & $\mathrm{kl} \mathrm{Itr}$ & 2,056 & 2,331 & 3,428 & 4,407 & 3,621 \\
\hline MFO & $\mathrm{kl} \mathrm{Itr}$ & 1,957 & 2,093 & 2,235 & 1,944 & 2,054 \\
\hline IDO & $\mathrm{kl} \mathrm{Itr}$ & 4 & 4 & 4 & 4 & 2 \\
\hline Gas & MMBTU & 163,792 & 160,044 & 144,675 & 140,498 & 144,244 \\
\hline Coal & ton & 10,423 & 11,437 & 10,541 & 12,016 & 13,753 \\
\hline
\end{tabular}

\subsection{Perhitungan Build Margin}

Dalam perhitungan Buid Margin sesuai dengan ACM0002, sebelumnya dilakukan pemilihan 2 kelompok unit pembangkit. Ada dua pilihan grup pembangkit yaitu: grup pembangkit yang terdiri dari 5 pembangkit terbaru dan grup pembangkit yang 
menghasilkan 20\% (atau lebih) dari total listrik terkoneksi dengan sistem JAMALI. Dari dua cara ini, dipilih kumpulan pembangkit penghasil listrik yang lebih besar. Perbedaan listrik hasil dari kedua kelompok tersebut ditunjukkan di tabel 3.

Dengan menggunakan jumlah emisi karbon dalam $\mathrm{t}-\mathrm{CO}_{2}$, dan $\mathrm{MWh}$ dan dengan menggunakan persamaan 8 , didapat $\mathrm{EF}_{\mathrm{BM}_{2006}}$ $=0.938 \mathrm{t}-\mathrm{CO}_{2} / \mathrm{MWh}$. Dalam perhitungan BM ini beberapa pembangkit terbaru dimiliki oleh pembangkit listrik swasta atau Independent Power Producer. Data konsumsi bahan bakar dari pembangkit-pembangkit ini tidak diketahui (tidak tercatat di buku stastik PLN). Untuk itu konsumsi bahan bakar dari pembangkit swasta dihitung berdasarkan disain efisiensi unit pembangkit listrik. Hasil perhitungan tersebut ditunjukkan di tabel 4 .

Gambar 6 menunjukkan hasil perhitungan $\mathrm{EF}_{\text {JAMALI2004 }}$ oleh Chevron (1) yang dihitung tahun 2006 dengan data statistik tahun 2002-2004, dan EF JAMALI2006 $_{\text {oleh }}$ PTPSE-BPPT ${ }^{(19)}$, dihitung tahun 2008 dengan data statistik tahun 2004-2006. Perhitungan $\mathrm{EF}_{\text {JAMALI } 2006}$ memakai persamaan (1), yang merupakan nilai rata rata $\mathrm{EF}_{\mathrm{OM}(2003-2005)}$

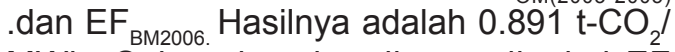
MWh. Sebagai perbandingan dipakai EF dari tenaga kelistrikan di grid Semenanjung Malaysia pada tahun 2004(20).

Dari hasil perhitungan, EF JAMALI2006, dibandingkan dengan $\mathrm{EF}_{\text {JAMALI2004, }}$, mengalami kenaikan sebesar $18.2 \%$, dari $0.754 \mathrm{t}-\mathrm{CO}_{2} /$ MWh meningkat ke $0.891 \mathrm{t}-\mathrm{CO}_{2} / \mathrm{MWh}$.

Peningkatan EF ini disebabkan adanya pembangunan pembangkit listrik berbahan bakar fosil pada kurun waktu 2004-2006. Pembangkit tersebut adalah PLTG BBM Muara Tawar Blok 2 \& 4 (858 MW), PLTU batubara Tanjung Jati B (1320MW) dan PLTGU gas Cilegon (740 MW). Pertambahan pembangkit listrik di sistem JAMALI ini tidak diimbangi dengan penambahan pembangkit berbahan bakar energi terbarukan atau peningkatan efisiensi pembangkit yang ada sehingga menyebabkan emisi karbon meningkat dari $68 \%$ ke $71 \%$, dalam kurun

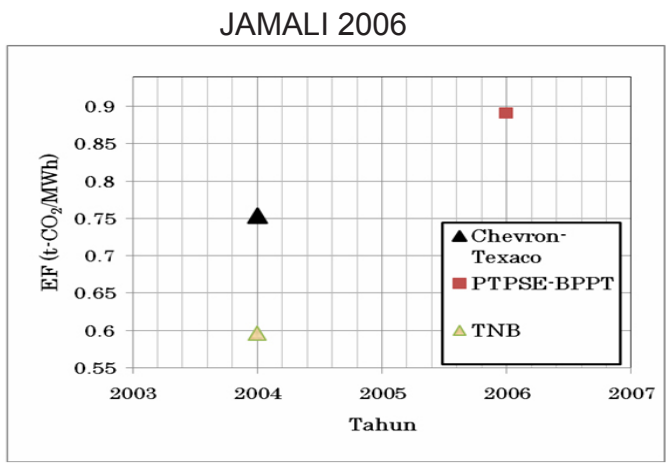

Gambar 6 Perubahan Faktor Emisi JAMALI

waktu tahun 2002-2006. Dari Gambar 4, dapat diketahui dengan jelas konsumsi batubara cenderung meningkat dari tahun ke tahun. Batubara memiliki nilai rasio karbon terbesar dari pembangkit lainnya (gambar 4). Pelaksanaan Program Percepatan Pembangunan PLTU batubara dengan kapasitas total $10.000 \mathrm{MW}^{(2)}$, mempunyai dampak meningkatkan besarnya emisi karbon setahap demi setahap.

Untuk menghitung $\mathrm{EF}_{2006}$ ini digunakan rata rata jumlah emisi karbon dalam $\mathrm{t}-\mathrm{CO}_{2}$ dan net listrik yang dihasilkan dalam kurun waktu 3 tahun terakhir. Hasilnya adalah 0.844 $\mathrm{t}-\mathrm{CO}_{2} / \mathrm{MWh}$. Pemilihan pemakaian nilar ratarata ini berdasarkan ACM0002 dimana jika rasio pembangkit LCMR lebih besar 50\% selama 5 tahun berturut-turut maka dapat menggunakan cara nilai rata-rata. Rasio tersebut ditunjukkan pada tabel 3.

Emisi faktor dari grid Malaysia, 0,597 $\mathrm{t}-\mathrm{CO}_{2} / \mathrm{MWh}^{(20)}$ pada tahun 2004 dimana angka ini jelas lebih rendah dari grid JAMALI di tahun yang sama. Nilai EF lebih rendah ini tercapai karena komposisi pembangkit di grid Malaysia sekitar 59.8\% adalah PLTGU gas.

Dimana efisiensi PLTGU jelas lebih tinggi dari PLTU batubara dan emisi faktor dari gas lebih rendah dari batubara. Kondisi ini membuat emisi faktor lebih rendah walaupun jumlah daya listrik yang terkoneksi dengan grid Malaysia pada tahun 2004 adalah 80.277 GWh. Sebagai perbandingan daya listrik yang terkoneksi di grid JAMALI pada tahun yang sama adalah 102.413 GWh dengan PLTU 
konsumsi batubara di atas $68 \%$.

Untuk mengejar pemenuhan kebutuhan listrik di sistem ketenagalistrikan JAMALI, pembangunan PLTU berbahan bakar batubara merupakan alternatif yang tidak terelakkan. Dampak dari pembangunan ini membuat sistem JAMALI sama sekali tidak mendukung usaha pengurangan emisi karbon dalam rangka pengurangan pemanasan global.

Pengurangan emisi karbon dari hasil pembakaran dapat diusahakan dengan membangun PLTU batubara yang mempunyai efisiensi tinggi sehingga akan mengurangi rasio $\mathrm{CO}_{2} / \mathrm{MWh}$ dari PLTU batubara. Pembangunan PLTU berbahan bakar gas dan pembangunan pembangkit energi terbarukan skala besar, PLTA atau PLTN akan dapat mengurangi emisi karbon di sistem JAMALI.

\section{KESIMPULAN}

Komposisi pembangkit di grid JAMALI yang 50\% lebih adalah PLTU batubara menyebabkan emisi karbon yang dihasilkan pembangkit listrik yang terkoneksi dengan grid JAMALI menjadi cenderung tinggi. Hasil perhitungan faktor emisi dalam 2004 dan 2006, juga menunjukkan kecenderungan kenaikan.

Terkait dengan issue pemanasan global perencanaan dan pengoperasian pembangkit Isitrik di grid JAMALI belum memprioritaskan untuk usaha pengurangan emisi karbon masih memprioritaskan pemenuhan energi nasional untuk mendukung pembangunan nasional.

Hasil perhitungan EF JAMAL 2006 oleh PTPSE-BPPT diakui dan telah diadopsi oleh Direktorat Jenderal Listrik \& Pemanfaatan Energi ${ }^{(19)}$ serta Komisi Nasional Mekanisme Pembangunan Bersih ${ }^{(21)}$ untuk dijadikan National Number bagi perhitungan emisi karbon untuk pembangkit listrik yang terkoneksi dengan JAMALI grid, untuk kurun waktu 2004-2006.

\section{DAFTAR PUSTAKA}

1) Anonim, 2006, Indonesian DNA official letter concerning baseline emission factor for CDM projects connected to JAMALI grid, September 12, 2006, No: B-5915/Dep.III/LH/09/06

2) Anonim, 2006,Perpres No. 71 Tahun 2006 tentang penugasan kepada PT. PLN (Persero) untuk melakukan percepatan pembangunan pembangkit tenaga listrik dengan menggunakan bahan bakar batubara.

3) Anonim, 2007, Tool to calculate the emission factor for an electricity system" (version 01, 19 October 2007, EB35, Annex 12).

4) Anonim, 2006, ACM (Approved Consolidation Methodology) 0002 version ke 6, "Consolidated methodology for grid-connected electricity generation from renewable sources". 19 May 2006, UNFCCC.

5) Anonim, 2006, "Approved small-scales methodologies", http://cdm.unfccc.int/ methodologies/SSCmethodologies/ approved.html

6) Anonim, 2002, Buku Statistik PT PLN (Persero)

7) Anonim, 2003, Buku Statistik PT PLN (Persero)

8) Anonim, 2004, Buku Statistik PT PLN (Persero)

9) Anonim, 2005, Buku Statistik PT PLN (Persero)

10) Anonim, 2006, Buku Statistik PT PLN (Persero)

11) Anonim, 2002, Buku Statistik PT Indonesia Power (PT IP)

12) Anonim, 2003,Buku Statistik PT IP

13) Anonim, 2004,Buku Statistik PT IP

14) Anonim, 2005,Buku Statistik PT IP

15) Anonim, 2006,Buku Statistik PT IP

16) Anonim, 2006, Buku Statistik PT Pembangkit Jawa Bali, 2002-2006

17) Anonim, 2004, Buku Statistik, Indonesia Coal \& Mineral 2004, Direktorat Jenderal Geologi dan Sumberdaya Mineral, Departement Energi \& Sumberdaya Mineral. 
18) Anonim, 2006,Buku Statistik, Indonesia Coal \& Mineral 2006, Direktorat Jenderal Geologi dan Sumberdaya Mineral, Departement Energi \& Sumberdaya Mineral.

19) Anonim, 2008, Baseline Faktor Emisi Sistem ketenagalistrikan Sumatera dan Updating baseline Faktor Emisi Sistem JAMALI, No:3783/21/600.5/2008 DJLPE- Departement ESDM.
20) Anonim, 2005, Mitsubishi Securities Clean Energy Finance Committee, PDD document, entitle of "MIMD biomass power generation project in Kuantan, Malaysia (The Project)".

21) Anonim, 2009, Informasi terbaru baseline faktor emisi untuk proyek CDM pada system ketenagalistrikan Sumatera dan JAMALI, No: B-277/Dep. III/LH/01/2009, Kementerian Negara Lingkungan Hidup, 19 Januari 2009.

Tabel 2. Pembangkit Listrik di Sistem JAMALI (6)(7)(8)

\begin{tabular}{|c|c|c|c|c|c|c|}
\hline \multirow{3}{*}{ Source of Power Plant } & \multirow{3}{*}{ fuel } & \multicolumn{5}{|c|}{ Operation Year } \\
\hline & & 2002 & 2003 & 2004 & 2005 & 2006 \\
\hline & & \multicolumn{5}{|c|}{ GWh } \\
\hline Hydro & & 6,910 & 5,346 & 6,042 & 7,057 & 5,339 \\
\hline Diesel & Oil & 87 & 60 & 66 & 128 & 101 \\
\hline \multirow[t]{2}{*}{ Gas Turbine } & Gas & 62 & 508 & 709 & 642 & 505 \\
\hline & Oil & 7,023 & 7,209 & 6,879 & 7,522 & 6,054 \\
\hline Geothermal & & 5,981 & 6,099 & 6,393 & 6,328 & 6,330 \\
\hline \multirow{4}{*}{ Steam } & Coal & 37,915 & 42,308 & 43,980 & 46,202 & 52,838 \\
\hline & Oil & 6,645 & 7,226 & 7,292 & 6,668 & 7,162 \\
\hline & Gas & 1,324 & 1,177 & 1,030 & 646 & 669 \\
\hline & Oil & 6,660 & 7,233 & 7,299 & 6,673 & 7,171 \\
\hline \multirow[t]{2}{*}{ Combined Cycle } & Gas & 19,016 & 18,098 & 17,486 & 16,559 & 16,224 \\
\hline & Oil & 3,976 & 3,860 & 5,237 & 7,943 & 7,473 \\
\hline \multicolumn{2}{|l|}{ TOTAL NET PRODUCTION } & 95,599 & 99,124 & 102,413 & 106,367 & 109,867 \\
\hline
\end{tabular}

Table 3: Pemilihan Grup Pembangkit Listrik

\begin{tabular}{|c|c|c|c|}
\hline Sample group $(\mathrm{m})$ Classification & $\begin{array}{c}\text { "The five power plants } \\
\text { that have been built } \\
\text { recently" (MWh) }\end{array}$ & $\begin{array}{c}\text { "The power plants capacity } \\
\text { addition to the electricity } \\
\text { system that comprises 20\% } \\
\text { of system generation ( in } \\
\text { MWh) and that have been } \\
\text { built most recently" }\end{array}$ & Comments \\
\hline \hline Electricity quantity & $8,168.2$ & $28,973,555$ & $\begin{array}{c}\text { Total } \\
\text { generation } \\
\text { is } 100,104 \\
\text { (GWh) in } \\
\text { JAMALI grid }\end{array}$ \\
\hline Selected group & $0.01 \%$ & $28.95 \%$ & \\
\hline
\end{tabular}




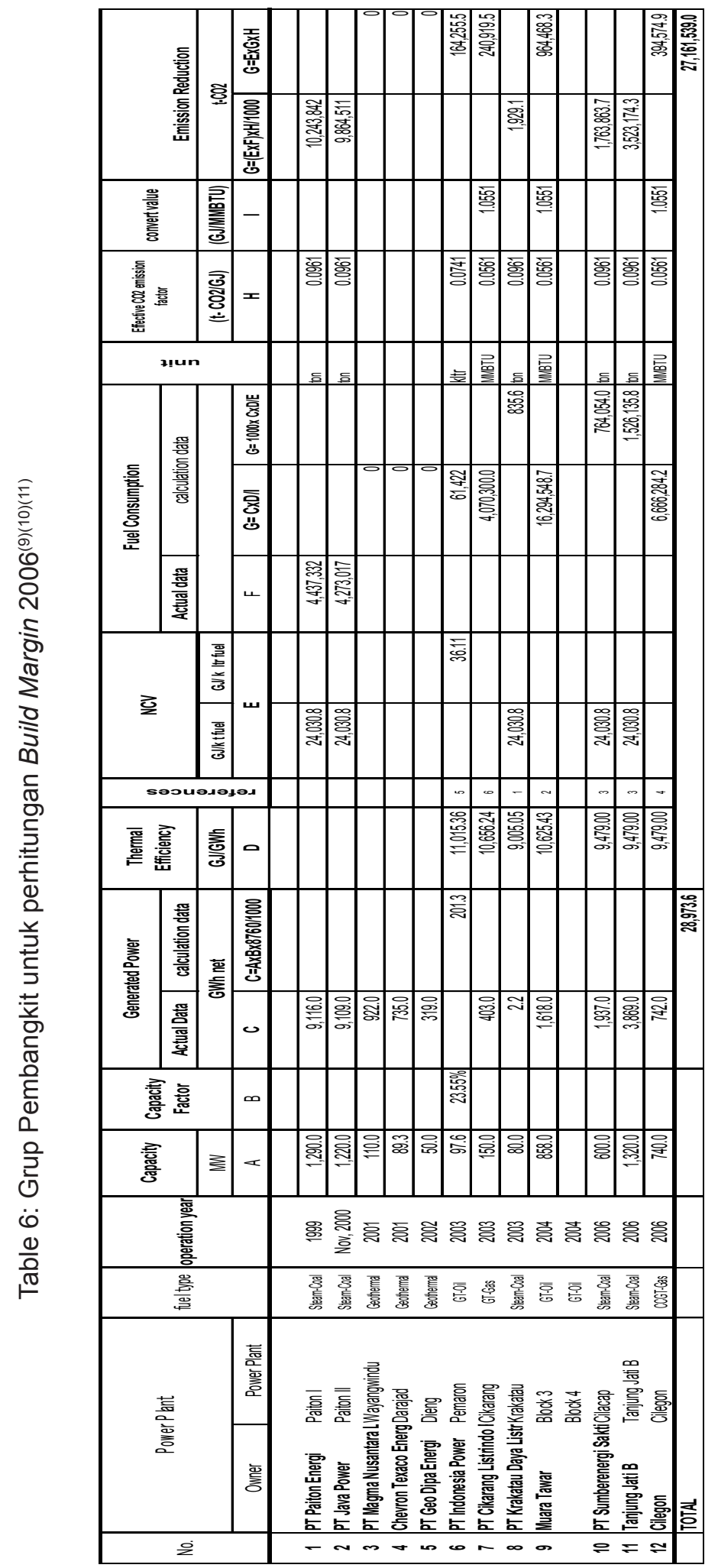

Perhitungan Faktor Emisi..., J. Tek. Ling. 11 (2): 227-237 